\title{
Determination of 2'-5'-Oligoadenylate Synthetase in Serum and Peripheral Blood Mononuclear Cells before and after Subcutaneous Application of Recombinant Interferon beta and gamma
}

\author{
By G. Bruchelt ${ }^{1}$, G. Fierlbeck ${ }^{2}$, Ursula Schiebel ${ }^{2}, O$. Bogenschütz ${ }^{2}, G$. Rassner $^{2}$ and D. Niethammer ${ }^{1}$ \\ 1 Universitäts-Kinderklinik, Tübingen, Germany \\ ${ }^{2}$ Universitäts-Hautklinik, Tübingen, Germany
}

(Received February 25, 1992)

\begin{abstract}
Summary: The interferon-inducible enzyme, $2^{\prime}-5^{\prime}$-oligoadenylate synthetase, was estimated in healthy donors and in patients before and after subcutaneous application of recombinant interferon beta and gamma. Tests were carried out with lysates of peripheral blood mononuclear cells, using an established radioenzymatic assay, and in serum samples, using a new radioimmunoassay. Both test systems substantially yielded the same results: after a single injection of interferon beta $\left(1-5 \times 10^{6} \mathrm{IU}\right), 2^{\prime}-5^{\prime}$-oligoadenylate synthetase increased in a dose-dependent manner reaching maximal catalytic concentrations in most patients after $24-48$ hours (leukocytes) and 48-72 hours (serum). In contrast, interferon gamma $\left(2-4 \times 10^{6} \mathrm{IU}\right)$ caused only a small induction of $2^{\prime}-5^{\prime}$-oligoadenylate synthetase. However, daily application of interferon gamma for 7 days led to a distinct time-dependent increase of $2^{\prime}-5^{\prime}$-oligoadenylate synthetase activity concentration during this observation period. Characteristically, even during daily application, the $2^{\prime}-5^{\prime}$-oligoadenylate synthetase activity concentration dropped just $48-72$ hours after the first injection of interferon beta.
\end{abstract}

The determination of $2^{\prime}-5^{\prime}$-oligoadenylate snythetase proved to be useful for optimizing and monitoring subcutaneous therapy with interferon. The new radioimmunoassay which allows the determination of this enzyme in serum is superior to other methods used in the past.

\section{Introduction}

The treatment of most cells with all kinds of interferon leads to the induction of $2^{\prime}-5$-oligoadenylate synthetase $\left.{ }^{1}\right)$ in vitro and in vivo $(1-3)$. This enzyme is part of the $2^{\prime}-5^{\prime}$-oligoadenylate system which represents one of the effector mechanisms of interferon's antiviral action and which may also be involved in its antiproliferative $(4,5)$ and immunoregulative (6) processes. The determination of $2^{\prime}-5$-oligoadenylate synthetase has been widely used as a quantity in clinical chemistry: Several interferon-related diseases

\footnotetext{
1) Enzyme:

2'-5'-oligoadenylate synthetase, EC 2.7.7. -
}

have been characterized by abnormal catalytic concentrations of this enzyme in leukocytes and in serum (7-15). Furthermore, the determination of $2^{\prime}-5^{\prime}$-oligoadenylate synthetase in leukocytes proved to be useful in the follow-up of intravenous (i.v.) and intramuscular (i.m.) interferon therapy $(16-21)$. Its measurement was often found to be superior to the estimation of interferon in serum, because not only does it indicate the presence of interferon, but also its biological activity. $2^{\prime}-5^{\prime}$-Oligoadenylate synthetase activity was also estimated directly in tumour tissue during therapy with interferon and it was demonstrated that the therapeutic success was correlated with the induced intratumour enzyme activity concentration (22). 
For clinical studies, most determinations of $2^{\prime}-5^{\prime}$ oligoadenylate synthetase have so far been performed in extracts of leukocytes. Despite their usefulness for many investigations, these tests are time consuming and are suitable particularly for retrospective studies (23). Recently, a sensitive radioimmunoassay has been developed which permits the determination of $2^{\prime}-5^{\prime}$ oligoadenylate synthetase in serum samples (24).

In the present study we compare the 2 '-5'-oligoadenylate synthetase activity in both leukocytes (using the radioenzymatic assay according to Schattner (25)) and in serum samples (using the radioimmunoassay described by Sawai (24)). Blood was obtained from healthy donors and from patients before and during therapy with recombinant interferon beta and gamma, which had been applied subcutaneousely (s.c.). Our aim was to find out whether or not this new assay could be used for the determination of $2^{\prime}$ 5 -oligoadenylate synthetase in serum as a follow-up marker during subcutaneous interferon therapy, since there were no data in the literature on this question.

\section{Materials and Methods}

Individuals

The control group consisted of healthy female and male blood donors (24-42 years old).

Other blood samples were obtained from patients suffering from different dermatological diseases.

\section{Blood samples}

Heparinized blood was drawn from healthy donors or from patients, from the latter both before and after s.c. application of interferon. Leukocytes were isolated by centrifugation using Lymphoprep (Nyegaard, Oslo, Norway) as described (23). For in vitro experiments, leukocytes $\left(2 \times 10^{9} / 1\right)$ were incubated at $37^{\circ} \mathrm{C}$ for 12,24 , and $48 \mathrm{~h}$ with interferon beta or gamma $(100$ $\left.\times 10^{3} \mathrm{IU} / \mathrm{l}\right)$ in minimal essential medium (MEM), supplemented with human serum (volume fraction 0.05 ) from AB blood group donors. After incubation, cell pellets were prepared and frozen at $-70^{\circ} \mathrm{C}$ until use.

\section{Interferons and their determination}

Recombinant Interferon beta (Betaferon ${ }^{\circledR}$ ) and recombinant Interferon gamma (Polyferon ${ }^{\circledR}, 2 \times 10^{6} \mathrm{IU}$ corresponding 100 $\mu \mathrm{g})$ were obtained from Bioferon / Rentschler, Laupheim, Germany. Concentrations of interferon gamma in serum were measured using the Gamma Interferon IRMA assay from Byk Sangtec Diagnostica, Dietzenbach, Germany; Interferon beta in serum was determined using a biological assay as described (26).

Determination of $2^{\prime}-5^{\prime}$-oligoadenylate synthetase in leukocytes

This enzyme was determined by a slightly modified procedure of the assay according to Schattner (25), and is described in detail elsewhere (23).
Briefly, $20 \mu \mathrm{l}$ of leukocyte lysate $\left(20 \times 10^{9} / 1\right)$ were bound to poly $(\mathrm{rI})(\mathrm{rC})$-agarose beads; after washing, the poly(rI)(rC): $2^{\prime}-5^{\prime}$-oligoadenylate synthetase complex was mixed with a $5 \mathrm{mmol} / 1\left[\alpha^{32} \mathrm{P}\right]$ ATP-containing buffer and incubated for 20 hours at $30^{\circ} \mathrm{C}$ for generation of radiolabelled $2^{\prime}-5^{\prime}$-oligoadenylates.

Subsequently, samples were treated with bacterial alkaline phosphatase. The $2^{\prime}-5^{\prime}$-oligoadenylate cores formed by this process were separated from ${ }^{32} \mathrm{P}$ by passage through an alumina column. Eluted $2^{\prime}-5^{\prime}$-oligoadenylate cores were estimated by Cerenkovradiation. Enzyme activity is given as \% radioactivity incorporated into $2^{\prime}-5^{\prime}$-oligoadenylate cores per hour per $10^{6}$ cells. The $2{ }^{\prime}-5^{\prime}$-oligoadenylate synthetase activity of patients' samples was related to an internal standard. For this purpose, lysates of leukocytes from 5 healthy persons were prepared in large quantities and frozen in several aliquots at $-70^{\circ} \mathrm{C}$. Samples of these 5 donors were always analysed in parallel with the patients' samples. The mean of $2^{\prime}-5^{\prime}$-oligoadenylate synthetase activity of the healthy donors was arbitrarily set at 1.0 and the $2^{\prime}-5^{\prime}$-oligoadenylate synthetase activities of the patients' samples were related to this value. All experiments were carried out in duplicate; the CV usually ranged between $4-12 \%$.

Determination of $2^{\prime}-5^{\prime}$-oligoadenylate synthetase activity in serum

The radioimmunoassay of EIKEN (Immunological Laboratory Kita-ku, Tokyo, Japan), provided by Mecconti, Bad Homburg, Germany, was used. The test was carried out according to the manufacturer's instructions:

First, serum samples $(50 \mu \mathrm{l})$ were incubated with poly(rI)(rC)agarose beads for 10 minutes at room temperature. After washing, beads were incubated with $500 \mu$ incubation buffer containing unlabelled ATP at a concentration of $40 \mu \mathrm{mol} / 1$. After incubation for one hour at $37^{\circ} \mathrm{C}$ (formation of "cold" $2^{\prime}-5^{\prime}$ oligoadenylate), $100 \mu \mathrm{l}$ of ${ }^{125}$ I-labelled $2^{\prime}-5^{\prime}$-oligoadenylate solution (tracer) and $100 \mu \mathrm{l}$ of antiserum directed against $2^{\prime}-5^{\prime}$ oligoadenylate were added, and incubation carried out for an additional hour at $37^{\circ} \mathrm{C}$ (formation of antigen-antibody complex).

Thereafter, samples were centrifuged at $4{ }^{\circ} \mathrm{C}$ at $6000 \mathrm{~g}$ for 15 minutes, the supernatant was removed and the radioactivity in the pellet was measured. A calibration curve using known $2^{\prime}-5^{\prime}$-oligoadenylate concentrations was established; the $2^{\prime}-5^{\prime}-$ oligoadenylate synthetase activity is expressed as $2^{\prime}-5^{\prime}$-oligoadenylate (pmol/l) produced under the test conditions during one hour incubation time. The determinations were carried out in duplicate (CV below 5\%).

\section{Results}

$2^{\prime}-5^{\prime}$-Oligoadenylate synthetase activity in leukocytes of healthy persons

In order to estimate $2^{\prime}-5^{\prime}$-oligoadenylate synthetase catalytic concentrations in leukocytes of patients, it is recommended that they be compared with a reference collective. For this purpose, lysates of leukocytes from 5 healthy donors were prepared in large quantities and stored in aliquots at $-70^{\circ} \mathrm{C}$. Under these conditions, the enzyme is stable for several months. These samples were analysed in parallel with the patients' samples in all further experiments. Figure 1 shows, as an example, the $2^{\prime}-5^{\prime}$-oligoadenylate syn- 


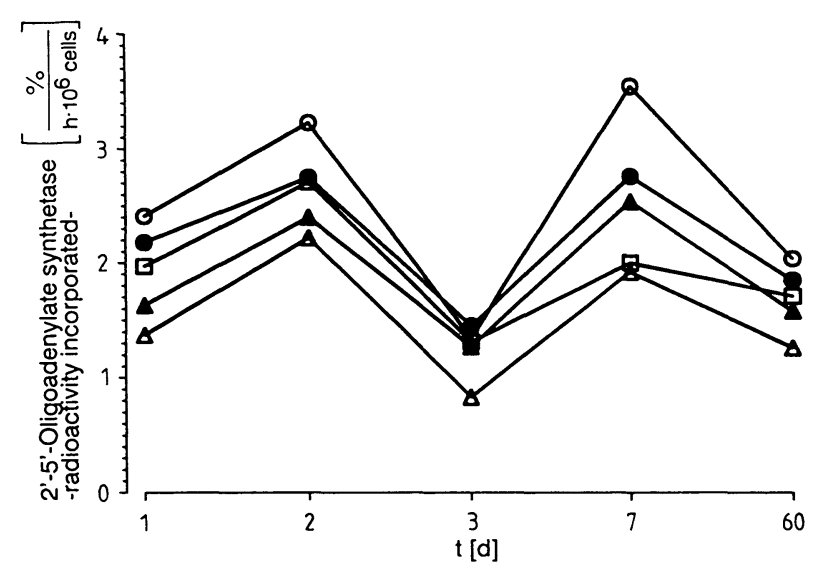

Fig. 1. 2'-5'-Oligoadenylate synthetase activity (expressed as percent radioactivity incorporated per hour per $10^{6}$ leukocytes) of cell lysates from 5 healthy donors measured on 5 different days during an observation period of 60 days (reference collective).

thetase activity of these healthy donors measured on 5 different days during a total observation period of 2 months. The mean of $2^{\prime}-5^{\prime}$-oligoadenylate synthetase activities estimated in percent radioactivity incorporated into $2^{\prime}-5^{\prime}$-oligoadenylate cores per hour per $10^{6}$ cells were:

$1.91 \pm 0.34($ day 1$)$
$2.63 \pm 0.36($ day 2$)$
$1.24 \pm 0.21($ day 3$)$
$2.55 \pm 0.59($ day 7$)$
$1.69 \pm 0.26($ day 60$)$

The mean of $2^{\prime}-5^{\prime}$-oligoadenylate synthetase activity of these 5 donors estimated in each experiment was arbitrarily set at 1.0 and patients' samples measured on the same day were related to this mean. In this way, determinations of $2^{\prime}-5^{\prime}$-oligoadenylate synthetase activities in leukocytes can be best followed over a long time period.

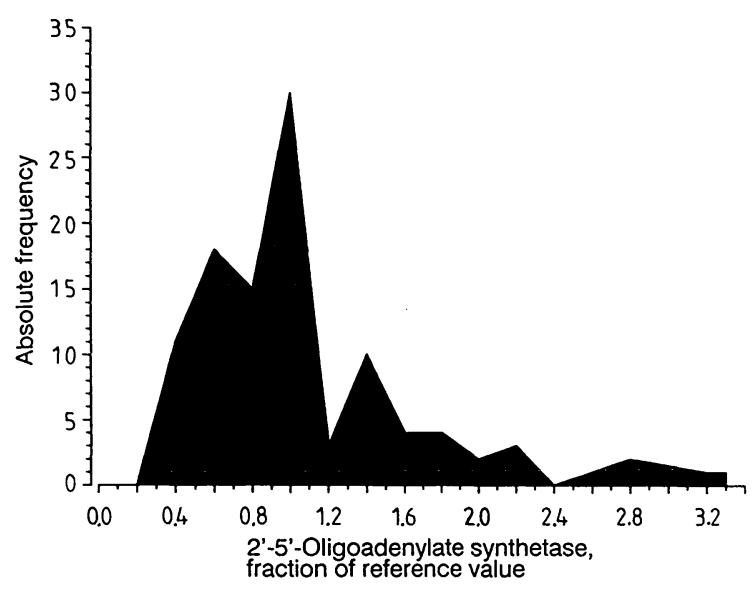

Fig. 2. Distribution of $2^{\prime}-5^{\prime}$-oligoadenylate synthetase activity in lysates of leukocytes from 104 healthy donors in relation to the reference collective (set at 1.0). Mean: $0.97 \pm 0.58$.
Figure 2 shows the $2^{\prime}-5^{\prime}$-oligoadenylate synthetase activity in leukocytes of healthy persons (related to reference collectives) measured in our laboratory during the last few years. In the majority of cases, the $2^{\prime}-5^{\prime}$-oligoadenylate synthetase activities of these persons were very similar to those of the respective reference collective (mean: $0.97 \pm 0.58 ; n=104$ ). Distinctly elevated $2^{\prime}-5^{\prime}$-oligoadenylate synthetase activities observed in a small number of cases might reflect the temporary occurrence of hidden viral infections (see also fig. 3).

$2^{\prime}-5^{\prime}$-Oligoadenylate synthetase activity in leukocytes after in vitro treatment with interferons

The clinical studies described below were carried out using recombinant interferon beta and gamma. Therefore, the effects of these interferons on $2^{\prime}-5^{\prime}$-oligoadenylate synthetase induction were first investigated in vitro in order to obtain information on their enzymeinducing capacity. As shown in table 1, 2'-5'-oligoadenylate synthetase was clearly induced by incubation with interferon beta, whereas only minor effects were observed when interferon gamma was used.

Tab. 1. Mean $2^{\prime}-5^{\prime}$-oligoadenylate synthetase activity in leukocytes from 10 healthy donors before and after in vitro incubation with interferon gamma $\left(100 \times 10^{3}\right.$ $\mathrm{IU} / \mathrm{l})$ and interferon beta $\left(100 \times 10^{3} \mathrm{IU} / \mathrm{l}\right)$ for 12,24 and 48 hours)

\begin{tabular}{|c|c|c|}
\hline $\begin{array}{l}\text { Incubation } \\
\text { time }\end{array}$ & $\begin{array}{l}\text { Interferon } \\
\text { gamma }\end{array}$ & $\begin{array}{l}\text { Interferon } \\
\text { beta }\end{array}$ \\
\hline 0 & \multicolumn{2}{|c|}{$0.93 \pm 0.55^{*}$} \\
\hline 12 & $1.03 \pm 0.66$ & $1.55 \pm 0.82$ \\
\hline 24 & $1.25 \pm 0.66$ & $2.46 \pm 0.86$ \\
\hline 48 & $0.88 \pm 0.38$ & $2.37 \pm 1.07$ \\
\hline
\end{tabular}

* 2 '-5'-oligoadenylate synthetase activity is expressed in relation to the reference collective given in figure 1 (arbitrarily set at 1.0)

$2^{\prime}-5^{\prime}$-Oligoadenylate synthetase activity in serum of healthy persons

Figure 3 shows the basal 2'-5'-oligoadenylate synthetase catalytic concentrations in the sera of 54 healthy persons. The mean 2'-5'-oligoadenylate concentration generated during the one hour incubation time was $186 \pm 84 \mathrm{pmol} / \mathrm{l}$. As already described for lysates of leukocytes, in a small number of persons the $2^{\prime}-5^{\prime}$ oligoadenylate synthetase activity was distinctly elevated. However, no correlation between the $2^{\prime}-5^{\prime}$ oligoadenylate synthetase measured in leukocytes (using the radioenzymatic assay) and in the corresponding sera (using the radioimmunoassay) were detected 


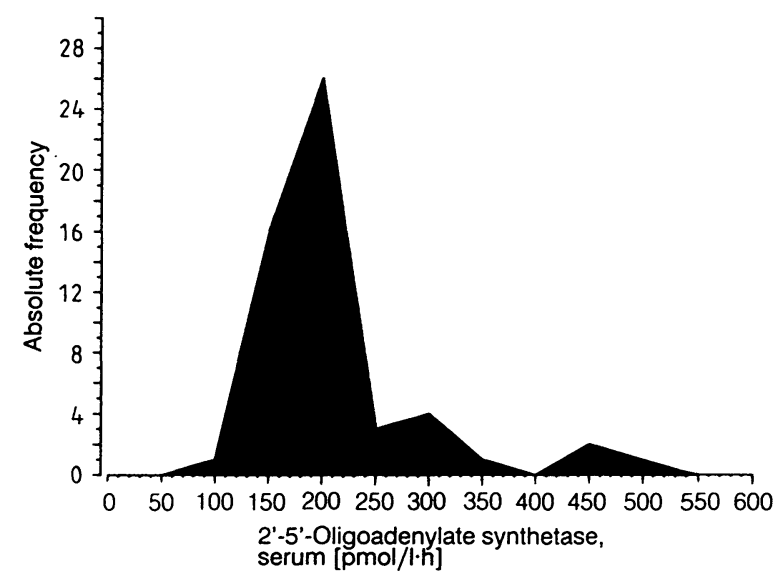

Fig. 3. 2'-5'-Oligoadenylate synthetase activity in serum samples of 54 healthy donors. Data are expressed as pmol/1 $2^{\prime}-5^{\prime}$-oligoadenylates generated under the test conditions described. Mean: $186 \pm 84 \mathrm{pmol} / \mathrm{l} \cdot \mathrm{h}$.

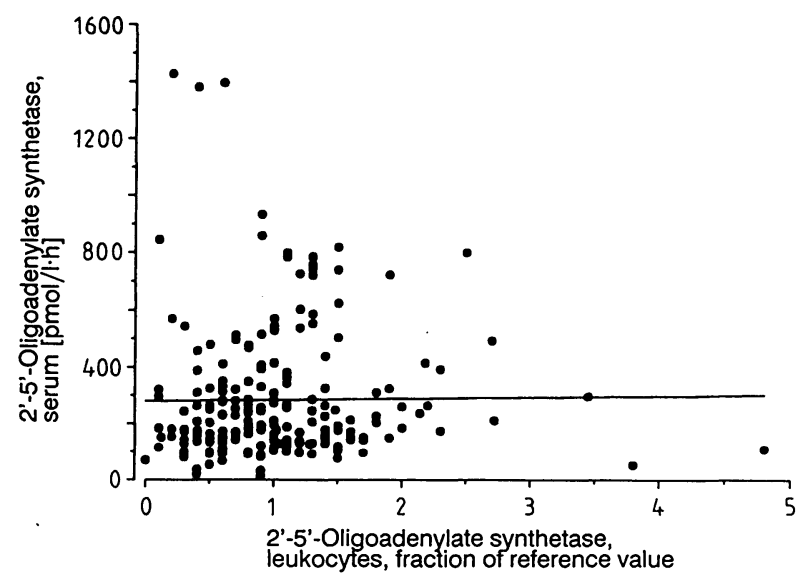

Fig. 4. Correlation between $2^{\prime}-5^{\prime}$-oligoadenylate synthetase activity in serum (measured by RIA) and in lysates of leukocytes (measured by radioenzymatic assay). The enzyme was determined in blood samples of healthy donors and patients before interferon therapy $(r=0.011)$.

(healthy donors and patients before interferon therapy, fig. 4).

$2^{\prime}-5^{\prime}$-Oligoadenylate synthetase in serum and leukocytes during subcutaneous therapy with interferon beta and gamma (single dose application)

Figure 5 shows the changes in $2^{\prime}-5^{\prime}$-oligoadenylate synthetase after single s.c. injections of different amounts of interferon beta. A distinct dose- and timedependent elevation of the mean 2 '-5'-oligoadenylate synthetase activity was observed in serum (fig. 5a, peak at about $48-72$ hours), as well as in leukocytes (fig. $5 \mathrm{~b}$, peak at about $24-48$ hours). In addition, the time course of the interferon concentrations (fig. $5 e)$ as well as those of the $2^{\prime}$-5'-oligoadenylate synthetase induction measured in serum (fig. 5c) and in lysates of leukocytes (fig. 5d) of three arbitrarily chosen patients in this collective is shown after treatment with $3 \times 10^{6}$ IU interferon beta. In all the cases investigated, enzyme induction occurred, although there were large individual differences.

Analogous investigations were carried out in patients after single dose therapy with interferon gamma. As shown in figure $6 \mathrm{a}-6 \mathrm{~d}$, the induction of $2^{\prime}-5^{\prime}$-oligoadenylate synthetase was much less pronounced than after treatment with interferon beta.

2'-5'-Oligoadenylate synthetase in leukocytes during subcutaneous therapy with interferon beta and gamma (daily dose application for 7 days)

Striking differences in $2^{\prime}-5^{\prime}$-oligoadenylate synthetase induction were observed after daily application of interferon beta and gamma: A permanent small increase in the $2^{\prime}-5^{\prime}$-oligoadenylate synthetase activity was registered after daily application of interferon gamma (fig. 7). In contrast, during therapy with interferon beta, the $2^{\prime}-5^{\prime}$-oligoadenylate synthetase decreased at $72 \mathrm{~h}\left(3 \times 10^{6} \mathrm{IU}\right)$ or $48 \mathrm{~h}\left(5 \times 10^{6} \mathrm{IU}\right)$ after the first application of the interferon (fig. 8).

\section{Discussion}

The estimation of interferon during therapy and for diagnosis has been performed in many patients in the past. The purpose was to determine the pharmacokinetics of the different kinds of interferon, to establish appropriate time schedules for the application, and to determine the appropriate dose and the manner of administration (intravenously, intramuscularly or sucutaneously) for different interferons. These investigations showed that interferon's half life time in serum is short and that the detectable concentrations are rather low. Thus, in our own investigation reported here, we could never detect interferon beta when the subcutaneously applied dosage was smaller than $3 \times 10^{6}$ IU per injection. Small, but only transient concentrations of interferon gamma could be registered in most patients treated s.c. with $2-4$ $\times 10^{6} \mathrm{IU}$. For this reason the determination of the interferon-induced enzyme, 2 '-5'-oligoadenylate synthetase, has some principal advantages compared with the analysis of interferon. However, there are no data in the literature concerning the kinetics of $2^{\prime}-5^{\prime}$-oligoadenylate synthetase induction after s.c. applica- 

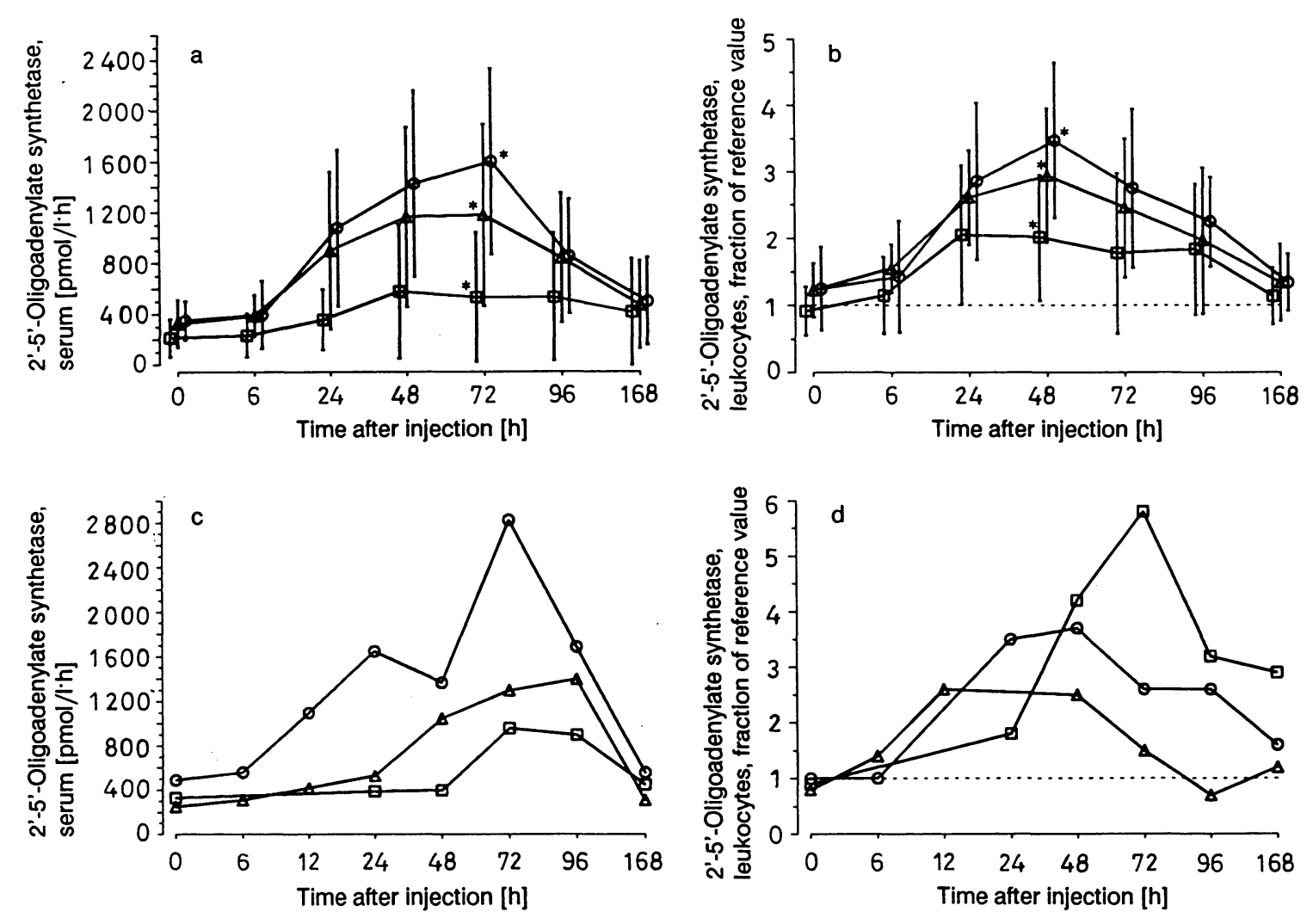

e

\begin{tabular}{|c|c|c|c|c|c|c|c|c|c|}
\hline & & \multicolumn{8}{|c|}{ Time after application [h] } \\
\hline \multicolumn{2}{|c|}{ Patient } & 0 & 6 & 12 & 24 & 48 & 72 & 96 & 168 \\
\hline 1 & 0 & 0.00 & 2.20 & 2.40 & 4.40 & 0.00 & 0.00 & 0.00 & 0.00 \\
\hline 2 & 口 & 1.80 & n.d. & n. d. & 2.80 & 4.20 & 2.60 & 2.80 & 2.80 \\
\hline 3 & $\Delta$ & 1.90 & 1.90 & 1.90 & 2.70 & 1.90 & 1.90 & 1.90 & 1.90 \\
\hline
\end{tabular}

n.d. not determined

Fig. 5. 2'-5'-Oligoadenylate synthetase activity in serum and leukocytes after a single s.c. injection of different amounts of interferon beta during an observation period of 168 hours; $n=$ number of patients. Student's t-test: ${ }^{*} \mathrm{p}<0.05$

a: Mean $2^{\prime}-5^{\prime}$-oligoadenylate synthetase activity in serum

$-0-5 \times 10^{6} \mathrm{IU}, \mathrm{n}=13 ;-\Delta-3 \times 10^{6} \mathrm{IU}, \mathrm{n}=13 ;-\square-1 \times 10^{6} \mathrm{IU}, \mathrm{n}=10$

b: Mean $2^{\prime}-5^{\prime}$-oligoadenylate synthetase activity in leukocytes

$-0-5 \times 10^{6} \mathrm{IU}, \mathrm{n}=10 ;-\Delta-3 \times 10^{6} \mathrm{IU}, \mathrm{n}=10 ;-\square-1 \times 10^{6} \mathrm{IU}, \mathrm{n}=7$

c: $2^{\prime}-5^{\prime}$-oligoadenylate synthetase activity in serum after application of $3 \times 10^{6} \mathrm{IU}$ interferon beta $(3$ randomly chosen patients)

d: $2^{\prime}-5^{\prime}$-oligoadenylate synthetase activity in lysates of leukocytes after application of $3 \times 10^{6}$ IU interferon-beta (same patients as shown in fig. 5c)

e: Interferon beta $\left[10^{3} \mathrm{IU} / \mathrm{l}\right]$ in serum of these three patients.

tion of recombinant interferon beta and gamma. In order to answer this question we determined the activity of 2'-5'-oligoadenylate synthetase in leukocytes (radioenzymatic assay) and in serum samples using a new commercial radioimmunoassay. This latter assay proved to be very practical and yielded well reproducible results. Basal 2'-5'-oligoadenylate synthetase catalytic concentrations of healthy donors were established and found to be within a range similar to that reported elsewhere (27). To obtain accurate results with this assay, it is obviously important to separate the serum immediately after the drawing of blood and coagulation, since blood storage causes an increase in the $2^{\prime}-5^{\prime}$-oligoadenylate synthetase due to release of the enzyme from blood cells (27).

The fundamental pattern of 2'-5'-oligoadenylate synthetase activity in serum was found to be similar to that in leukocytes. However, in contrast to reported data (27), we could not find a direct correlation between $2^{\prime}-5^{\prime}$-oligoadenylate synthetase in serum and $2^{\prime}-5^{\prime}$-oligoadenylate synthetase in leukocytes from the 

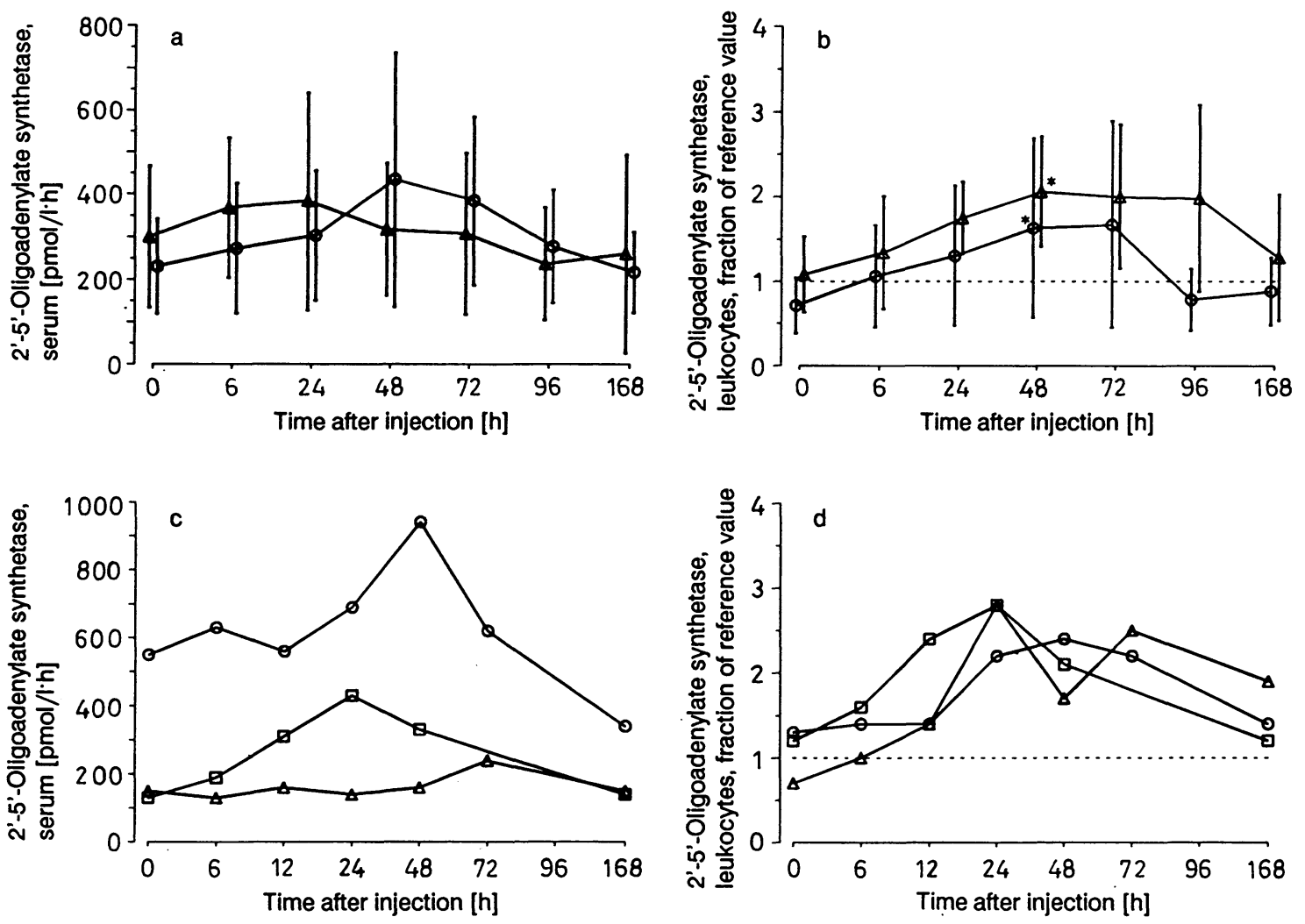

e

\begin{tabular}{|c|c|c|c|c|c|c|c|c|c|}
\hline & & \multicolumn{8}{|c|}{ Time after application [h] } \\
\hline \multicolumn{2}{|c|}{ Patient } & 0 & 6 & 12 & 24 & 48 & 72 & 96 & 168 \\
\hline 1 & 0 & 0.15 & 5.90 & 2.10 & 0.00 & 0.00 & 1.00 & 0.00 & 1.30 \\
\hline 2 & $\square$ & 0.00 & 3.80 & 2.20 & 0.00 & 0.00 & 0.00 & 0.00 & 0.20 \\
\hline 3 & $\Delta$ & 0.00 & 1.70 & 0.70 & 1.00 & 0.60 & 0.30 & 0.00 & 0.00 \\
\hline
\end{tabular}

Fig. 6. $2^{\prime}-5^{\prime}$-Oligoadenylate synthetase activity in serum and leukocytes after a single s. c. injection of 2 and $4 \times 10^{6} \mathrm{IU}(100$ and $200 \mu \mathrm{g}$, respectively) interferon gamma during an observation period of 168 hours; $\mathrm{n}=$ number of patients.

Student's t-test: ${ }^{*} \mathrm{p}<0.05$

a: Mean 2'-5'-oligoadenylate synthetase activity in serum $-0-200 \mu \mathrm{g}, \mathrm{n}=16 \quad-\Delta-100 \mu \mathrm{g}, \mathrm{n}=13$

b: Mean 2'-5'-oligoadenylate synthetase activity in leukocytes $-\triangle-200 \mu \mathrm{g}, \mathrm{n}=10 \quad-0-100 \mu \mathrm{g}, \mathrm{n}=11$

c: $2^{\prime}-5^{\prime}$-Oligoadenylate synthetase activity in serum after application of $4 \times 10^{6} \mathrm{IU}$ interferon gamma ( 3 randomly chosen patients)

d: $2^{\prime}-5^{\prime}$-Oligoadenylate synthetase activity in lysates of leukocytes after application of $4 \times 10^{6} \mathrm{IU}$ interferon gamma (same patients as shown in fig. 6c)

e: Interferon gamma $\left[10^{3} \mathrm{IU} / 1\right]$ in serum of these three patients.

same blood sample. This raises the question of where the serum 2'-5'-oligoadenylate synthetase comes from. Based on the data of our investigation and on theoretical considerations, it is improbable that $2^{\prime}-5^{\prime}$-oligoadenylate synthetase released from mononuclear blood cells is the main source of the activity in serum. Since $2^{\prime}-5^{\prime}$-oligoadenylate synthetase can be induced in many cells, this enzyme may be released from almost every cell in the body which had previously come in contact with interferon. Main potential sources are, e.g. cells at and near to the site of interferon injection. In blood, granulocytes may play an even more important role than mononuclear blood cells, because their $2^{\prime}-5^{\prime}$-oligoadenylate synthetase can be easily induced (28), they are fragile, present in high numbers, and have a short half life. However, whatever the source of $2^{\prime}-5^{\prime}$-oligoadenylate synthetase, its estimation in serum proved to be as informative as its estimation in leukocytes. Moreover, the enzyme immunoassay in serum is much easier to perform than the radioenzymatic assay. Results of both assays showed that after subcutaneous application of more 


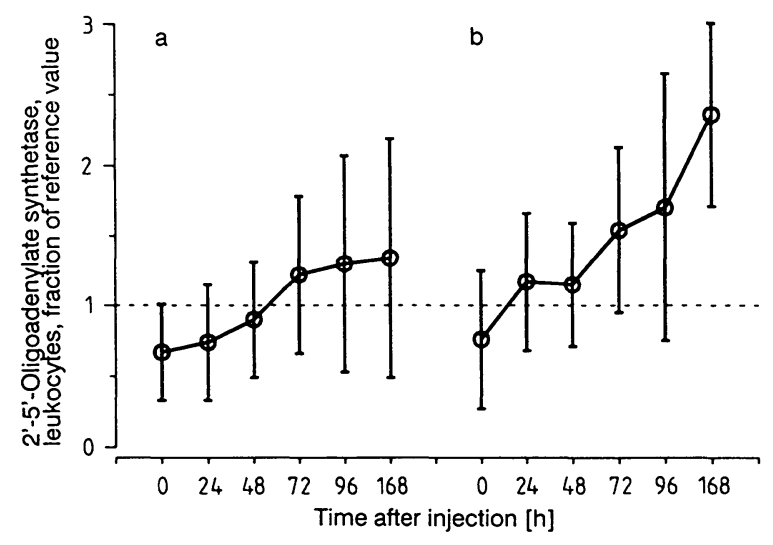

Fig. 7. Mean $2^{\prime}-5^{\prime}$-oligoadenylate synthetase activity in leukocytes during an observation period of 168 hours after daily ( 7 days) s. c. injections of interferon gamma; a) $100 \mu \mathrm{g}, \mathrm{n}=8$; b) $200 \mu \mathrm{g}, \mathrm{n}=6$; $\mathrm{n}=$ number of patients.

than $1 \times 10^{6} \mathrm{IU}$ interferon beta, $2^{\prime}-5^{\prime}$-oligoadenylate synthetase activity can be clearly detected; its determination proved to be much more sensitive than the estimation of interferon. In contrast, interferon gamma caused only a small elevation of $2^{\prime}-5^{\prime}$-oligoadenylate synthetase and, therefore, its determination as a follow up marker during single dose therapy is not recommended. 2'-5'-Oligoadenylate synthetase catalytic concentrations were well elevated after therapy with interferon beta, but not after therapy with interferon gamma; as shown in table 1, similar results were obtained for the in vitro stimulation of the enzyme levels. Interestingly, during a daily application therapy of interferon beta, the $2^{\prime}-5^{\prime}$-oligoadenylate synthetase activity dropped $2-3$ days after the first injection. This is obviously due to interferon recep-

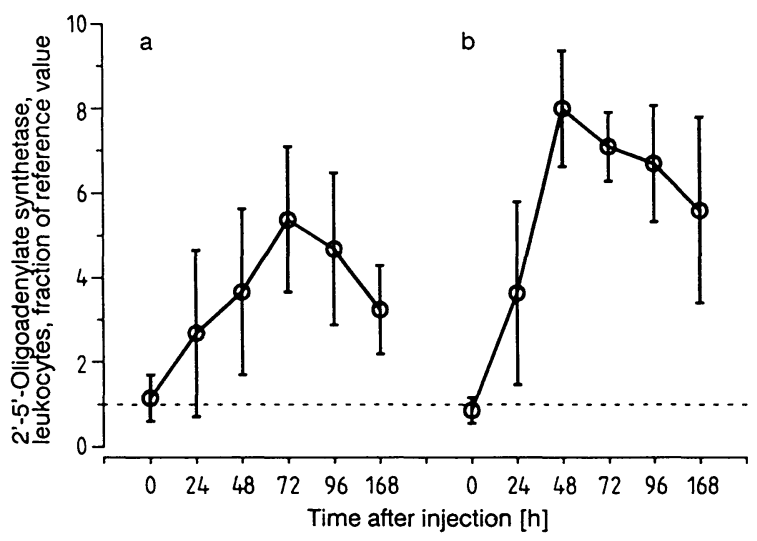

Fig. 8. Mean $2^{\prime}-5^{\prime}$-oligoadenylate synthetase activity in leukocytes during an observation period of 168 hours after daily (7 days) s. c. injections of interferon beta; a) $3 \times 10^{6} \mathrm{IU}, \mathrm{n}=8$; b) $5 \times 10^{6} \mathrm{IU}, \mathrm{n}=5$; $\mathrm{n}=$ number of patients.

tor down regulation phenomena (29). These data suggest that daily application of interferon beta should not be recommended for therapy. The schedule of interferon application was therefore changed for the therapy of further patients. In contrast, daily application of interferon gamma showed a permanent increase of $2^{\prime}-5^{\prime}$-oligoadenylate synthetase activity during the observation period of 7 days.

In conclusion, $2^{\prime}-5^{\prime}$-oligoadenylate synthetase proved to be a useful marker for optimizing subcutaneous therapy with recombinant interferon beta and gamma. The newly introduced radioimmunoassay which permits a rapid and convenient determination of this enzyme in serum is well suited for this purpose and superior to other methods used so far.

\section{References}

1. Stark, G. R., Brown, R. E. \& Kerr, I. M. (1981) Assay of (2-5)-Oligoadenylic acid synthetase levels in cells and tissues: a convenient poly(I)-poly(C) paper-bound enzyme assay. Methods Enzymol. 79, 194-199.

2. Chebath, J., Benech, P., Hovanessian, A., Galabrus, J. \& Revel, M. (1987) Four different forms of interferon-induced $2^{\prime}, 5^{\prime}$ oligo(A) synthetase identified by immunoblotting in human cells. J. Biol. Chem. 262, 3852-3857.

3. Pestka, S., Langer, J. A., Zoom, K. C. \& Samuel, Ch. E. (1987) Interferons and their actions. Ann. Rev. Biochem. $56,727-777$.

4. Johnson, M. I. \& Torrence, P. E. (1984) The role of interferon-induced proteins, double-stranded RNA and $2^{\prime}, 5^{\prime}$ oligoadenylate in the interferon-mediated inhibition of viral translation. In: Interferon 3. Mechanism of Production and Action (Friedman, R. M., ed.) Elsevier, Amsterdam. pp. $189-298$.

5. Sen, G. C. (1984) Biological pathways in interferon actions. Pharmacol. Ther. 24, 235-257.

6. Schmidt, A., Crisp, B., Krause, D., Silvermann, R. H., Heberman, R. B. \& Ortaldo, J. R. (1987) Involvement of the $2^{\prime}-5^{\prime} \mathrm{A}$ pathway in the augmentation of natural killer activity. Nat. Immun. Cell Growth Regul. 6, 19-27.

7. Williams, B. R. G. \& Read, S. E. (1981) Detection of elevated level of the interferon-induced enzyme, 2-5 A synthetase in infectious diseases and on parturition. In: The Biology of the Interferon System (De Mayer, E., Galasso, G. \& Schellekens, H., eds) Elsevier, Amsterdam, pp. 111 114.

8. Schattner, A., Merlin, G., Hahn, T., Levin, S. \& Revel, M. (1981) Assay of an interferon induced enzyme in white blood cells as a diagnostic aid in viral diseases. Lancet II, $397-499$.

9. Preble, O. T., Rothko, K., Klippel, J. H., Friedman, R. M. \& Johnston, M. I. (1983) Interferon-induced $2^{\prime}$-5' adenylate synthetase in vivo and interferon production in vitro by lymphocytes from systemic lupus erythematosus patients with and without circulating interferon. J. Exp. Med. 157, $2140-2146$. 
10. Read, St. E., LeBrocq, F. J. \& Williams, B. R. G. (1985) Persistent elevation of 2-5A synthetase and prognosis in the aids-related complex (ARC). Prog. Clin. Biol. Res. 202, 405-413.

11. Preble, O. T., Yeh, Tze-Jou, Silverman, R. H., Klippel, J. H., Straus, St. E. \& Gelmann, E. P. (1985) Interferon and 2-5A synthetase in patients with immune diseases. Proc. Clin. Biol. Res. 202, 415-422.

12. Sugino, H., Mitani, I., Koike, M., Kodama, T., Sokawa, J., Sawai, H., Ishibashi, K., Itoh, M., Watanabe, S. \& Sokawa, Y. (1986) Detection of elevated levels of 2-5A synthetase in serum from children with various infectious diseases. J. Clin. Microbiol. 24, 478-481.

13. Read, S. E., Williams, B. R. G., Coates, R. A., Evans, W K., Fanning, M. M., Garvey, M. B. \& Shepherd, F. A. (1985) Elevated levels of interferon-induced 2'-5'-oligoadenylate synthetase in generalized persistent lymphadenopathy and the acquired immunodeficiency syndrome. J. Infect. Dis. $152,466-472$.

14. Hearl, W. G. \& Johnston, M. I. (1987) Accumulation of $2^{\prime}-5^{\prime}$-oligoadenylate in encephalomyocarditis virus-infected mice. J. Virol. 61, 1586-1592.

15. Saito, T. (1986) $2^{\prime} 5^{\prime}$-Oligoadenylate synthetase activity in serum of healthy subjects and of homosexual men infected with human immunodeficiency virus. J. Tokyo Women's Medical College 56, 955-960.

16. Lodemann, E., Nitsche, E. M., Lang, M. H., Gerein, V., Altmeyer, P., Holzmann, H. \& Kornhuber, B. (1985) Serum interferon level and $\left(2^{\prime}-5^{\prime}\right)$ oligoadenylate synthetase activity in lymphocytes during clinical interferon application. J. Interferon Res. 5, 621-628.

17. Shindo, M., Okuno, T., Matsumoto, M., Takeda, M., Takino, T., Sokawa, J., Iwata, A. \& Sokawa, Y. (1988) Serum $2^{\prime}, 5^{\prime}$-oligoadenylate synthetase activity during interferon treatment of chronic hepatitis B. Hepatology $8,366-370$.

18. Preble, O. T., Rook, A. H., Steis, R., Silverman, R. H., Krause, D., Quinnan, G. V., Masur, H., Jacob, J., Longo, D. \& Gelmann, E. P. (1985) Interferon-induced 2'-5'-oligoadenylate synthetase during interferon- $\alpha$ therapy in homosexual men with Kaposi's sarcoma: marked deficiency in biochemical response to interferon in patients with acquired immunodefiency syndrome. J. Infect. Dis. 152, 457465.
19. Merrit, J. A., Borden, E. C. \& Ball, L. A. (1985) Measurement of $2^{\prime}, 5^{\prime}$ oligoadenylate synthetase in patients receiving interferon-alpha. J. Interferon Res. 5, 191-194.

20. Furuta, M., Akashi, K., Nakamura, Y., Matsumoto, K., Yamaguchi, H., Takamatsu, S. \& Shimizu, T. (1987) 2',5'Oligoadenylate synthetase activity in peripheral blood lymphocytes as a clinical marker in interferon therapy for chronic hepatitis B. J. Interferon Res. 7, 111-119.

21. Östlund, L., Einhorn, S. \& Robert, K-H. (1986) Induction of $2^{\prime}, 5^{\prime}$-oligodenylate synthetase and blast transformation in primary chronic lymphocytic leukemia cells following exposure to interferon. Cancer Res. 46, 2160-2163.

22. Grander, D., Öberg, K., Lundquist, M-L., Janson, E. T., Eriksson, B. \& Einhorn, St. (1990) Interferon-induced enhancement of $2^{\prime}, 5^{\prime}$-oligoadenylate synthetase in mid-gut carcinoid tumours. Lancet 336, 337-340.

23. Bruchelt, G., Beck, J., Schilbach-Stückle, K., Koscielniak, E., Treuner, J. \& Niethammer, D. (1987) Methods for the determination of the interferon-induced enzyme $2^{\prime}-5$ '-oligoadenylate synthetase in mononuclear blood cells. J. Clin. Chem. Clin. Biochem. 25, 879-888.

24. Sawai, H., Ishibashi, K., Itoh, M. \& Watanabe, S. (1985) Sensitive radioimmuno assay for $2^{\prime}, 5^{\prime}$-oligoadenylates using a novel ${ }^{125}$ I-labeled derivative of $2^{\prime}, 5^{\prime}$-triadenylate $5^{\prime}$-triphosphate. J. Biochem. 98, 999-1005.

25. Schattner, A., Merlin, G., Wallach, D., Rosenberg, H., Bino, T., Hahn, T., Levin, S. \& Revel, M. (1981) Monitoring of interferon therapy by assay of $\left(2^{\prime}-5^{\prime}\right)$ oligo-isoadenylate synthetase in human periphal white blood cells. J. Interferon Res. 1, 587-594.

26. Rubinstein, S., Familletti, P. C. \& Pestka, S. (1981) Convenient assay for interferons. J. Virol. 37, 757-758.

27. Sawai, H., Taira, H., Ishibashi, K., Itoh, M., Tanaka, H. \& Shigenobu, K. (1988) Detection of $2^{\prime}, 5^{\prime}$-oligoadenylate synthetase activity in serum and in supernatant of cultivated lymphocytes: response to interferons or interferon inducers. Biomed. Res. 9, 59-66.

28. Schattner, A., Merlin, G., Bregman, V., Hahn, T., Levin, S., Revel, M. \& Wallach, D. (1984) $\left(2^{\prime}-5^{\prime}\right)$ Oligo A synthetase in human polymorphonuclear cells increased activity in interferon treatment and in viral infections. Clin. Exp. Immunol. 57, 265-270.

29. Zoon, K. C. \& Arnheiter, H. (1984) Studies on the Interferon Receptors. Pharmacol. Ther. 24, 259-278.

\author{
Dr. Gernot Bruchelt \\ Universitäts-Kinderklinik \\ Abteilung II \\ Rümelinstraße 23 \\ W-7400 Tübingen \\ Bundesrepublik Deutschland
}

